ZIBELINE INTERNATIONAL

\title{
NATURAL TREATMENT TECHNOLOGY FOR CLEANING WASTEWATER
}

\author{
Anthony Wong
}

Frangipani Hotels \& Resorts Sdn Bhd *Email: nohazian@asianoverland.com.my

This is an open access article distributed under the Creative Commons Attribution License, which permits unrestricted use, distribution, and reproduction in any medium, provided the original work is properly cited

\section{ARTICLE DETAILS}

\section{Article history:}

Received 12 August 2016

Accepted 12 December 2016

Available online 20 January 2017

Keywords:

Phytoremediation, Constructed wetland, Natural treatment technology for wastewater

\section{INTRODUCTION}

Wetland utilization generates economic savings: because they rely on more natural methods, they are less expensive to build and operate than conventional sewage treatment (e.g., less electricity consumption); furthermore the purified water is suitable for reuse. Purified water for reuse is a very valuable asset as clean water is a scarce resource that is critical for human existence, to focus on preserving or constructing manmade wetlands in order to increase water availability over time and gain benefits from the ecosystem services provided.

\section{. Why built a Constructed Wetland}

\section{Domestic situation}

- If with a single septic tank, the soil percolation may be too high or too low, or other site conditions may be unfavorable for a percolation area alone.

- If soil percolation is too low then the septic tank effluent will not flow down through the percolation area but may instead pond on the surface of the lawn. If percolation is too high then the effluent will travel rapidly through the sandy or gravelly soil and pollute the groundwater. This is particularly undesirable if you or your neighbors have a well supplying their drinking water.

\section{Industrial situations}

- May find constructed wetlands suitable for dealing with effluents with high volume and relatively low toxicity or nutrient status. Wetlands have been used for the mining industry, food industry sector, metals industries for reclaiming metals and a variety of other wastes.

3. Benefit To Tourism Industry And Government

- To create the awareness for local and community the importance of wastewater treatment. 
- As for education sector, this is one way to educate student from the University to better understand the workings of the treatment process.

- Habitat for fish and wildlife, passive recreation such as hunting and bird watching and also for landscape enhancement.

- Can provide incentives for a place to preserve, regenerate and provide upkeep in their urban and wildlife areas.

- Visitors promote international links, which can provide more business and cultural connections in the medium to long term.

4. Economic, Environmental and Social Feasibility

? The creation of constructed wetland can also assist in changing the way people relate amongst themselves while at the same time promoting other alternatives of development. [? Strengthening community relationships with nature and understanding of ? Environmental conservation.

Plants in Wastewater Treatment

\section{?. Wetlands as Water Purification System}

Type of Plants in Wastewater Treatment Wetland

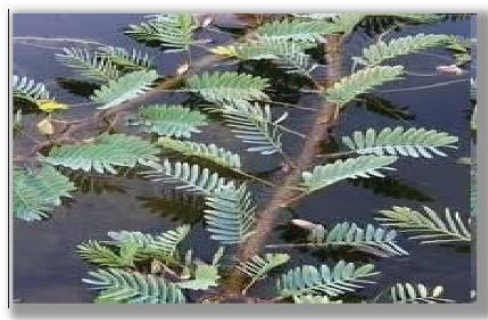

\section{Water Mimosa \\ (Neptunia oleracea)}

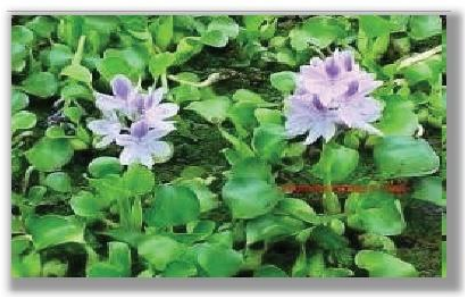

Water Hyacinth (Eichhornia crassipes)

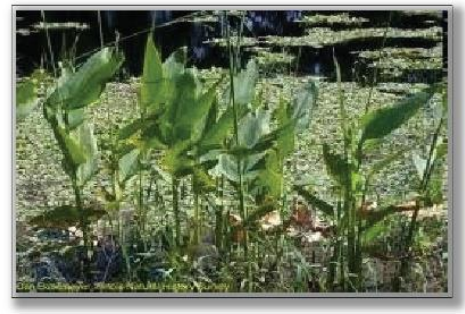

Red Stem Flag (Thalia Geniculata)

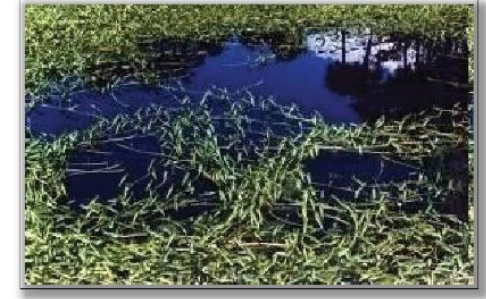

\section{Water Spinach (Ipomoea aquatic Forsskal)}

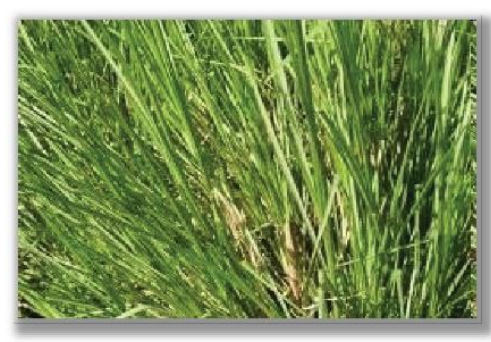

\section{Vertiver \\ (Veteveria zizaniodes)}

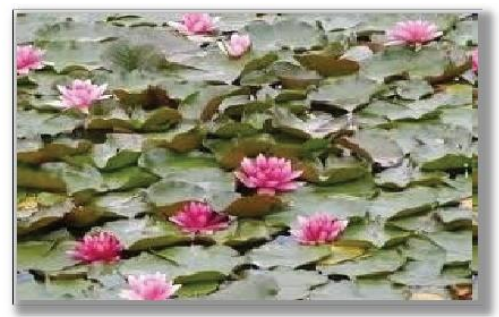

\section{Water Lily (Nymphaea)}

Wetlands cycle both sediments and nutrients balancing terrestrial and aquatic ecosystems.

Wetland systems possess bio-filters, hydrophytes and organisms that in addition to nutrients uptake abilities have the capacity to remove toxic substances that come from pesticides, industrial discharges and mining activities.

For example, floating plants [such as Eichhorniacrassipes Water Hyacinth) and Lemna

[Duckweed)]can absorb and filter heavy metals as well as store iron and copper commonly found in waste water. 
The Frangipani Langkawi Langkawi Resort \& Spa

\section{Sources of Wastewater in the Wetland}
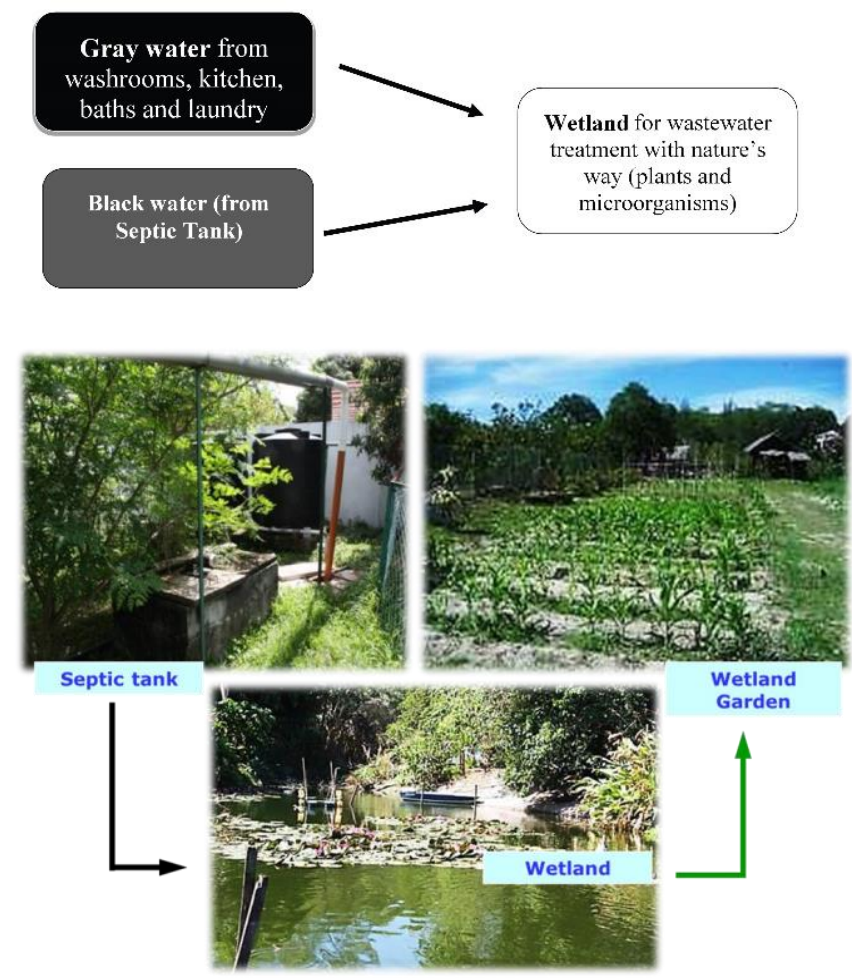

Wastewater Treatment Wetland Diagram

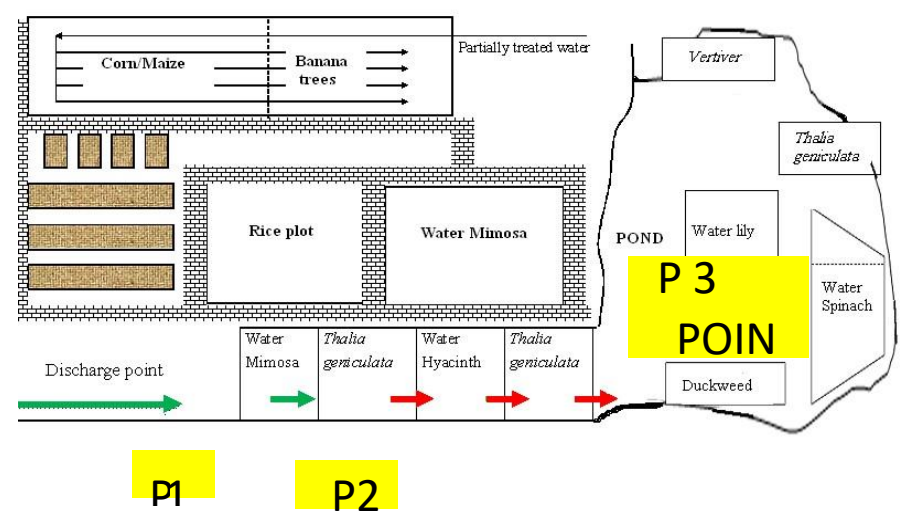

(3) The wetland area is about 0.5855 acres (2.369 sq $\mathrm{m}$ ) with a maximum depth

$1.2-1.7 \mathrm{~m}$ depending on the season.

- Average flow rate of the wastewater from discharge inlet to the inlet of the end of water mimosa $0.0034 \mathrm{~m} / \mathrm{s}$ (green arrow) and $0.0015 \mathrm{~m} / \mathrm{s}$ for Thalia Geniculata until Eichhorniacrassipes (red arrow).

- Total surface area for all the plants used in wastewater treatment system is $1363.73 \mathrm{sqm}$.

- Total surface area for Pandan is $443.10 \mathrm{sq}$ m.

- Total surface area for Water Mimosa and Water Hyacinth is $376.42 \mathrm{sq} \mathrm{m}$.

- Total surface area for Water Spinach is $58.25 \mathrm{sq} \mathrm{m}$.

- Total surface area for Water Lily is $68.83 \mathrm{sq} \mathrm{m}$.

- Total surface area for Vetiver is $79.20 \mathrm{sq} \mathrm{m}$.

- Total surface area for Bent Alligator Flag is $65.33 \mathrm{sq} \mathrm{m}$.
I. Waste Water Treatment (Wetland) Results for February 2017 At The Final Point (P3).

II. Test Description Analysis Result(s) Standard Spec. (A) Standard Spec. (B) Grade

\begin{tabular}{|c|c|c|c|c|}
\hline Temperature & $27.2 \mathrm{C}$ & 40 & 40 & A \\
\hline pH Value & 7.5 & $6.0-9.0$ & $5.5-9.0$ & A \\
\hline ROD & $12 \mathrm{mg} / 1$. & $20 \mathrm{mg} / \mathrm{t}$. & $50 \mathrm{mg} / \mathrm{t}$ & A \\
\hline C.OD - Chemical Oxygen Demand & $4.3 .1 \mathrm{mg} / \mathrm{L}$ & $80 \mathrm{mg} / \mathrm{L}$ & $200 \mathrm{mg} / \mathrm{L}$ & A \\
\hline Suspended Solids & $7.0 \mathrm{mg} / \mathrm{L}$ & $50 \mathrm{mg} / \mathrm{L}$ & $100 \mathrm{mg} / \mathrm{L}$ & $\boldsymbol{A}$ \\
\hline Mercury (as Hg) & $\mathrm{ND}<0.001 \mathrm{mg} / \mathrm{L}$ & $0.005 \mathrm{mg} / \mathrm{L}$ & $0.05 \mathrm{mg} / \mathrm{L}$ & $\Lambda$ \\
\hline Caslmiurr (as C.II) & $\mathrm{ND}<0.003 \mathrm{mg} / \mathrm{k}$ & $0.01 \mathrm{mg} / \mathrm{l}$. & $0.02 \mathrm{mg} / \mathrm{L}$. & A \\
\hline Chromium Ifexavalent & $N D<0.02 \mathrm{mg} / \mathrm{t}$. & $0.05 \mathrm{mg} / \mathrm{l}$. & $0.05 \mathrm{mg} / \mathrm{t}$. & $A$ \\
\hline Arsenic [as As] & $\mathrm{ND}<0.001 \mathrm{mg} / \mathrm{L}$ & $0.05 \mathrm{mg} / \mathrm{L}$ & $0.10 \mathrm{mg} / \mathrm{L}$ & $\Lambda$ \\
\hline Cyanide as $(\mathrm{N}$ ) & $\mathrm{ND}<0.02 \mathrm{mg} / \mathrm{L}$ & $0.05 \mathrm{mg} / \mathrm{L}$ & $0.10 \mathrm{mg} / \mathrm{L}$ & $\Lambda$ \\
\hline Lead & $\mathrm{ND}=0.01 \mathrm{mg} / \mathrm{L}$ & $0.10 \mathrm{mg} / \mathrm{h}$ & $0.5 \mathrm{mg} / \mathrm{L}$ & A \\
\hline Chromium Trivalent & $\mathrm{ND}<0.02 \mathrm{mg} / \mathrm{L}$ & $0.20 \mathrm{mg} / \mathrm{l}$ & $1.0 \mathrm{mg} / \mathrm{l}$. & A \\
\hline C.opper & $0.02 \mathrm{mg} / \mathrm{L}$ & $0.20 \mathrm{mg} / \mathrm{L}$ & $1.0 \mathrm{mg} / \mathrm{L}$ & $A$ \\
\hline Manganese & $0.07 \mathrm{mg} / \mathrm{L}$ & $0.20 \mathrm{mg} / \mathrm{L}$ & $1.0 \mathrm{mg} / \mathrm{L}$ & $\Lambda$ \\
\hline Nickel (as Ni) & $\mathrm{ND}<0.02 \mathrm{mg} / \mathrm{L}$ & $0.20 \mathrm{mg} / \mathrm{L}$ & $1.0 \mathrm{mg} / \mathrm{L}$ & $\mathbf{A}$ \\
\hline Zinc & $\mathrm{ND}=0.02 \mathrm{mg} / \mathrm{L}$ & $2.0 \mathrm{mg} / \mathrm{L}$ & $2.0 \mathrm{mg} / \mathrm{L}$ & A \\
\hline Boron [as B] & $0.3 \mathrm{mg} / \mathrm{L}$ & $1.0 \mathrm{mg} / \mathrm{L}$ & $4.0 \mathrm{mg} / \mathrm{L}$ & A \\
\hline Irron (as $\mathrm{Fc}$ ) & $0.3 \mathrm{mg} / \mathrm{L}$ & $1.0 \mathrm{mg} / \mathrm{L}$ & $5.0 \mathrm{mg} / \mathrm{L}$. & $A$ \\
\hline Phenol & $\mathrm{ND}<0.001 \mathrm{mg} / \mathrm{L}$ & $0.001 \mathrm{mg} / \mathrm{L}$ & $1.0 \mathrm{mg} / \mathrm{L}$ & $\Lambda$ \\
\hline Free Chlorine & $0.06 \mathrm{~m} \mathrm{~m} / \mathrm{L}$ & $1.0 \mathrm{mg} / \mathrm{L}$ & $20 \mathrm{mg} / \mathrm{L}$ & $\mathrm{A}$ \\
\hline Silver & $\mathrm{N} 0<<0.01 \mathrm{mg} / \mathrm{L}$ & $0.1 \mathrm{mg} / \mathrm{L}$ & $1.0 \mathrm{mg} / \mathrm{L}$ & $\mathrm{A}$ \\
\hline Aluminium & $\mathrm{ND}<0.01 \mathrm{mg} / \mathrm{L}$ & $10 \mathrm{mg} / \mathrm{L}$ & $1.5 \mathrm{mg} / \mathrm{L}$ & A \\
\hline Selenium & $\mathrm{ND}<0.001 \mathrm{mg} / \mathrm{L}$ & $0.02 \mathrm{mg} / \mathrm{L}$ & $0.5 \mathrm{mg} / \mathrm{L}$ & A \\
\hline Barium & $\mathrm{ND}<0.01 \mathrm{mg} / \mathrm{L}$ & $1.0 \mathrm{mg} / \mathrm{L}$ & $2.0 \mathrm{mg} / \mathrm{L}$ & A \\
\hline Fluoride & $0.8 \mathrm{mg} / \mathrm{L}$ & $2.0 \mathrm{mg} / \mathrm{L}$ & $5.0 \mathrm{mg} / \mathrm{L}$ & A \\
\hline Firrmaldechyde & $N D<0.01 \mathrm{mg} / \mathrm{s}$. & $1.0 \mathrm{mg} / \mathrm{I}$. & $2.0 \mathrm{mg} / \mathrm{t}$. & $\bar{A}$ \\
\hline Ammoniacal Nitrogen & $3.0 \mathrm{mg} / \mathrm{L}$ & $10 \mathrm{mg} / \mathrm{L}$ & $20.0 \mathrm{mg} / \mathrm{L}$ & A \\
\hline Colour & $80 \mathrm{ADMJ}$ & 100 & 200 & A \\
\hline Oil and Grease & $4.0 \mathrm{mg} / \mathrm{L}$ & 1.0 & 10.0 & $\boldsymbol{A}$ \\
\hline Phesphturus & $1.1 \mathrm{mg} / \mathrm{m}$. & & - & - \\
\hline Nitrate: & $0.2 \mathrm{mg} / \mathrm{t}$. & & & - \\
\hline E-coli & 8,000 cfu/ml & & & . \\
\hline Coliform & $19,000 \mathrm{cfu} / \mathrm{ml}$ & & - & . \\
\hline Tinal Rasteria C.munt. & 193,000 cfu/ $100 \mathrm{ml}$ & . & & . \\
\hline
\end{tabular}

Wetland Water Analysis 2017

Bacteria

- Bacteria counts from the latest water quality test results (taken in March 2015) are shown in the table.

- These counts are included in the water quality test because any exposure to sewage, contaminated soil and/or water poses a serious health risk and the wetland is used to treat all the sewage produced by the resort.

- The basic test for bacterial contamination of a water supply is the test for total coliform bacteria. Total coliform counts give a general indication of the sanitary condition of the water.

- Total coliform include the bacteria that are found in the soil, water that has been influenced by surface water and in human or animal waste. Reduce $99 \%$ after plants and microorganisms.

- Escherichia coli or E.coli is the major in the fecal coliform group. Reduce by $99 \%$ in less than 12 hours.

- The presence of E.coli in water is a strong indication that recent contamination by black water, sewage or animal waste has occurred. The degree of risk depends on the level of contamination and which type of bacteria is involved.

- $\quad$ E.coli stain releases endotoxins which can cause severe gastrointestinal illness involving diarrhea, cramps and occasionally kidney failure and death.

- In normal healthy adults, the disease is self-timing in about 5-10 days. It is young children and the elderly, who are most at risk.

- Thus, the success in the ability of plants in the wetland to take up E.coli can help to reduce the hazardous impact on the environment as well as on human health.

Biochemical Oxygen Demand (BOD) 
- $\quad$ BOD is the amount of oxygen required for microbial metabolism of organic compounds in water. This demand occurs over some variable period of time depending on temperature, nutrients concentrations and the enzymes available to indigenous microbial populations.

- The amount of oxygen required to completely oxidise the organic compounds to carbon dioxide and water through generations of microbial growth, death, decay and cannibalism is the total BOD.

- Dissolved oxygen depletion is most likely to become evident during the initial aquatic microbial population deoxgenates the water, that lack of oxygen imposes a limit on population growth of aerobic aquatic microbial organisms, thus resulting in a longer term food surplus and oxygen deficit. These large organic molecules are easily decompose by bacteria in the septic tank system.

- However, oxygen is required for this process of breaking large molecules into smaller molecules and eventually into carbon dioxide and water.

- $\quad$ The five-day BOD is measured by the most common measure of the amount of biodegradable organic material in or strength of sewage.

- $\quad$ BOD is fairly easy to remove from sewage by providing a supply of oxygen during the treatment process; the oxygen supports bacterial growth which breaks down the organic BOD.

\section{Phosphorus}

- Phosphorus is a constituent of human wastewater, averaging around $10 \mathrm{mg} / \mathrm{L}$ in most cases. The principal forms are organically bound phosphorus, polyphosphates and orthophosphates.

- $\quad$ Organically bound phosphorus originates from body and food waste upon biological decomposition of these solids, is converted to orthophosphates. Most household phosphate inputs now come from human waste and automatic dishwasher detergent.

- $\quad$ Phosphorus found in the wetland water is often the nutrient that limits growth of aquatic plants. Thus, when it is added to a body of water, it may result in increased plant growth like water hyacinth (Eichhorniacrassipes) that gradually fills in the lake.

- $\quad$ As these aquatic plants die, they sink to the bottom, where their decomposition by microorganism uses most of the oxygen dissolved in the water.

- $\quad$ The decrease in oxygen severely inhibits the growth of many aquatic organisms, especially more desirable fish and in extreme cases may lead to massive fish kills.

- Besides that, excessive input of phosphorus can change clear oxygen-rich, good tasting water into cloudy, oxygen - poor, foul smelling and possibly toxic water. Therefore, during wastewater treatment, control of the amount of phosphates by the aquatic plants such as water mimosa (Neptuniaolerace), water hyacinth (Eichhorniacrassipes) and duck weed (Lemna minor) are required to prevent eutrophiction.

- The effectiveness of those plants uptake could be proven through the phosphorus level in the wetland.

\section{Total Suspended Solids (TSS)}

- $\quad$ TSS is solids in water that can be trapped by a filter. It can include a wide variety of materials such as silt decaying plant and animal matter, industrial wastes and sewage.

- High concentration of suspended solids can cause many problems for stream health and aquatic life.

- $\quad$ High TSS can block light from reaching submerged vegetation. As the amount of light passing through the water is reduced photosynthesis slows down. Reduced rates of photosynthesis cause less dissolved oxygen to be released into water by plants.

- If light is completely blocked from bottom dwelling plants, the plants will stop producing oxygen and will die. As the plants are decomposed, bacteria will use up even more oxygen from the water. Low dissolved oxygen can lead to the killing of fish.

- High TSS can also cause an increase in surface water temperature, because the suspended particles absorb heat from sunlight. This can cause dissolved oxygen level to fall even further (because warmer waters can hold less dissolved oxygen) and can harm aquatic life.

- $\quad$ The decrease in water clarity caused by TSS can affect the ability of fish to see and catch food. Suspended sediment can also clog fish gills, reduce growth rates, decrease resistance to disease and prevent egg and larval development.

- When suspended solids settle to the bottom of a water body, they can smother the eggs of fish and aquatic insects as well as suffocate newly hatched insect larvae. Setting sediments can fill in spaces between rocks which could have been used by aquatic organism for homes. 